\title{
Improving Road Safety of Tank Truck in Indonesia by Speed Limiter Installation
}

\author{
Hadi Pranoto ${ }^{1,2 a}$, A.M Leman ${ }^{2}$,Ishak Baba $^{2}$,Dafit Feriyanto ${ }^{2}$ and Gama Widya Putra ${ }^{3}$ \\ ${ }^{1}$ Faculty of Mechanical Engineering, Mercubuana University, Jakarta,Indonesia \\ ${ }^{2}$ Faculty of Engineering Technology, Universiti Tun Hussein Onn Malaysia 86400 Parit Raja, Batu Pahat, Johor, Malaysia \\ ${ }^{3}$ Faculty of Public Health, Indonesia University, Jakarta Indonesia
}

\begin{abstract}
Indonesia has one of the highest number of fatalities caused by traffic accident. It is become main concern since last decades. Approximately of $10 \%$ fatalities is caused by tank truck accident, it recorded by PT. Pertamina Persero, Indonesia in 2015 that $17 \%$ and $20 \%$ tank truck accident is caused by over speed and fatigue, respectively. Therefore, over speed has become main factor the occurrence of tank truck accident. Main objective of this research is to install speed limiter on the tank truck in order to improve safety engineering system, decrease accident and to maintain engine performance. This research is conducted in Indonesia especially in Java-Bali route travel. Speed limiter is installed to the tank truck engine which completed by fuel cut-off solenoid to reduce the speed automatically when it exceeding the maximum speed that has been determined. From the result shows that top speed which performed by driver up to $133 \mathrm{~km} / \mathrm{h}$ when tank truck uninstalled by speed limiter. Meanwhile, when speed limiter is installed to the tank truck, top speed locked at $70 \mathrm{~km} / \mathrm{h}$ even though the driver want to speed up. It means that fuel cutoff system is very effective to lock the speed at $70 \mathrm{~km} / \mathrm{h}$ and it shown the improvement up to $65 \%$. The monitoring activities observed that the decreasing number of fatalities caused by tank truck accident become $7 \%$ as compared to last year of $17 \%$. It can be found that the speed limiter coupled by speed recorder was very efficient to improve safety engineering system of the tank truck.
\end{abstract}

\section{Introduction}

Traffic accident is one of the causes of the death in Indonesia because based on report of Indonesia Police Departement that close to 31.234 fatalites cause by trafic accident and it means that there are 3-4 fatalites/hour [1]. The rapid growth of vehicle and industrie will incerasse the signifiant proportion differences between vehicle and capacity of road. The average annual vehicle growth from 1996 to 2006 of $20 \%$ (Table 1) which may take a higher possibility in increasing road fatalities [2].

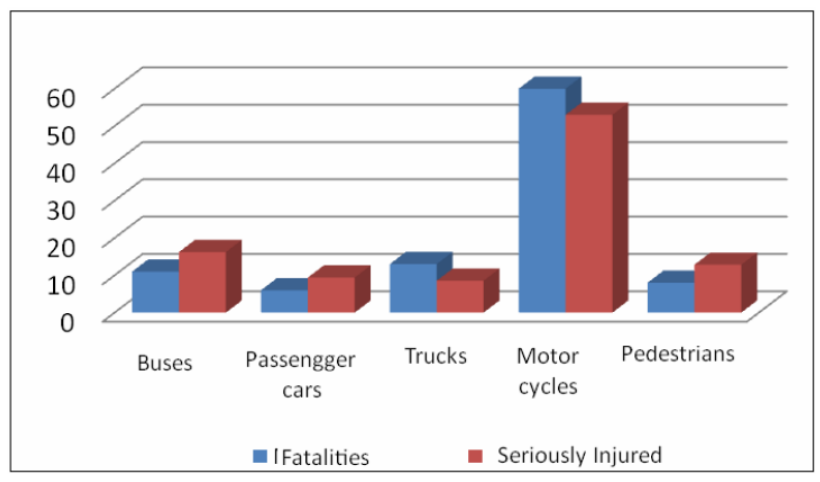

Figure 1 Percentage number victims by vehicle types [2]

\footnotetext{
${ }^{\mathrm{a}}$ Corresponding author : hadi.pranoto@mercubuana.org
}

Table 1 Number of vehicle growth in Indonesia [2]

\begin{tabular}{|c|c|c|}
\hline Year & $\begin{array}{c}\text { Total registered } \\
\text { vehicle }\end{array}$ & $\begin{array}{c}\text { Annual growth of } \\
\text { total vehicle (\%) }\end{array}$ \\
\hline 1996 & 14530095 & \\
\hline 1997 & 16821076 & 16 \\
\hline 1998 & 17644885 & 5 \\
\hline 1999 & 18224149 & 3 \\
\hline 2000 & 18975344 & 4 \\
\hline 2001 & 21201272 & 12 \\
\hline 2002 & 24671330 & 16 \\
\hline 2003 & 32774929 & 33 \\
\hline 2004 & 41986814 & 23 \\
\hline 2005 & 47654826 & 13 \\
\hline 2006 & 50102492 & 5 \\
\hline
\end{tabular}

Figure 1 shows that fatalities caused by tank truck approximately of $10 \%$ and it higher than buses, passenger car and pedestrian, even though motorcycle is the highest number of fatalities in Indonesia. Therefore, vehicle safety of tank truck is quite needed in order to reduce number of fatalities [2].

There many causes of tank truck accident such as fatigue, engine problems, over speed, attitude and external causes as shown in Figure 2. Fatigue and over speed contributes $20 \%$ and $17 \%$ of total tank truck 
accident. Therefore, it very needed to solve that problems to improve safety driving and reduce tank truck accident [3].

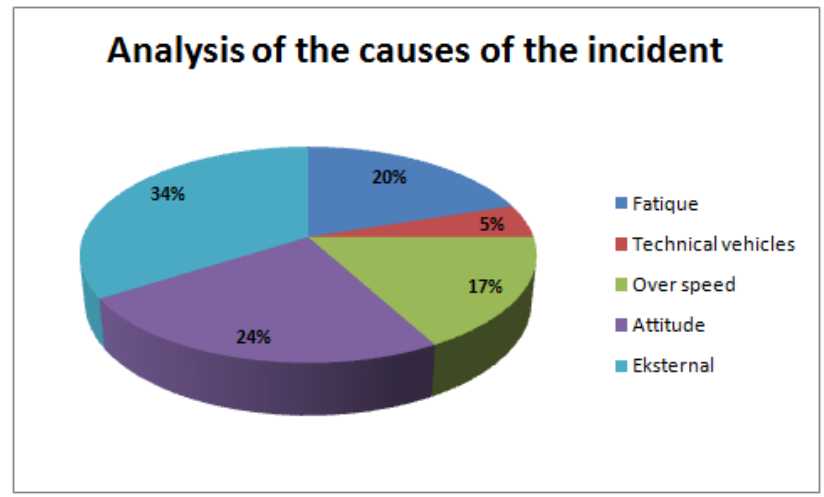

Figure 2 Several factor of tank truck accident

According to KLH (1999) [4], Constitution No. 22 (2009) [5] and Ministry of Transportation, Indonesia (2015) [6] issued the regulation of speed limit based on area which consists of maximum speed of $100 \mathrm{~km} / \mathrm{h}$ in highway, $80 \mathrm{~km} / \mathrm{h}$ in urban area, $50 \mathrm{~km} / \mathrm{h}$ in centre of urban area and $30 \mathrm{~km} / \mathrm{h}$ in residential area. Moreover, PT. Pertamina Persero (2013) [7] has issued the regulation that the maximum speed of the tank truck in highway is $70 \mathrm{~km} / \mathrm{h}$. This regulation was issued to reduce the accident rate. However there are many driver not obey that regulation. Therefore, installing the additional part in the engine to limit the speed is quite needed, which may reduce the accident rate. In this research innitiate to develop new speed limiter which coupled by fuel cut-off solenoide to limit the speed by reducing supply fuel into the engine.

\section{Methodology}

\subsection{Installation of speed limiter on the tank truck}

Speed limiter is installed to the tank truck of PT. Pertamina Persero. It managed more than 6,000 tank truck scattered throughout Indonesia. This research focus on the Installation Jakarta Group (IJG) which located in Plumpang and they operates approximately 257 tank trucks with a various payload capacity from 16,000 to 40,000 liters.

\subsection{Speed limiter installation}

The modification of speed limiter installation has been done by improvement on electrical wire, which placed and connected with the engine. Speed limiter able to limit the speed at the certain speeds based on government regulation depending on the urban or highway speed. The speed limiter installation procedure is shown in Figure 3 and Figure 4 where it consists of buzzer, ECU, speed sensor, engine and speed limiter control box.

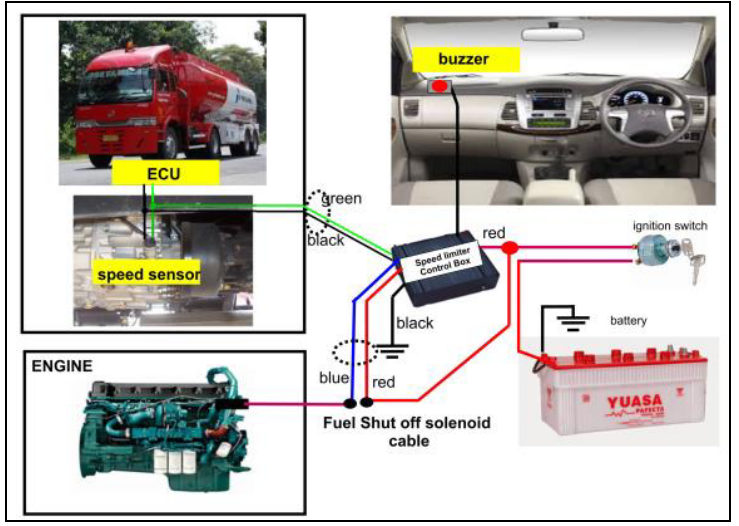

Figure 3. Diagram Installation engine truck

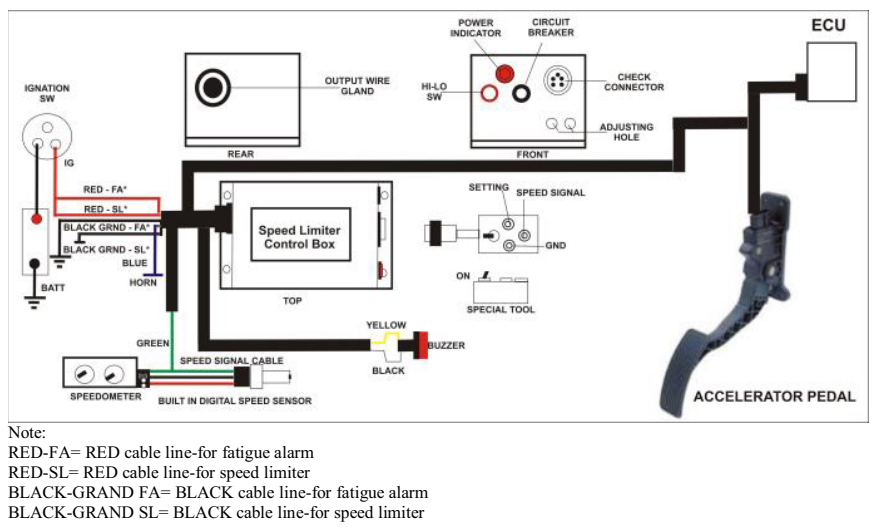

Figure 4 Schematic diagram of speed limiter

The working principle of the speed limiter mounted on the tank truck machine. When the vehicle speed exceeds of a specified speed limit, speed sensor at the transmission output will send signal frequency to accelerator pedal. it will be transformed into a voltage signal at IC program and voltage signal will be transformed into the comparators components, forwarded to relay and followed by sound a warning alarm buzzer. When the driver still perform additions speed, fuel cut-off solenoid will reduce the fuel consumption into the engine and it will reduce the speed/rpm to the normal speed. Meanwhile, when the driver is slow down the speed, the buzzer alarm will be stop and back to the normal speed.

\subsection{Speed reduction test}

The speed limiter is installed to the engine and it controlled and adapted by government regulation. Basic principle of speed limiter is performed when the tank truck in over speed and it wills automatically cut-off the fuel. It make a tank truck speed will be operated under top speed regulation. Schematic diagram of speed limiter is shown in Figure 5 


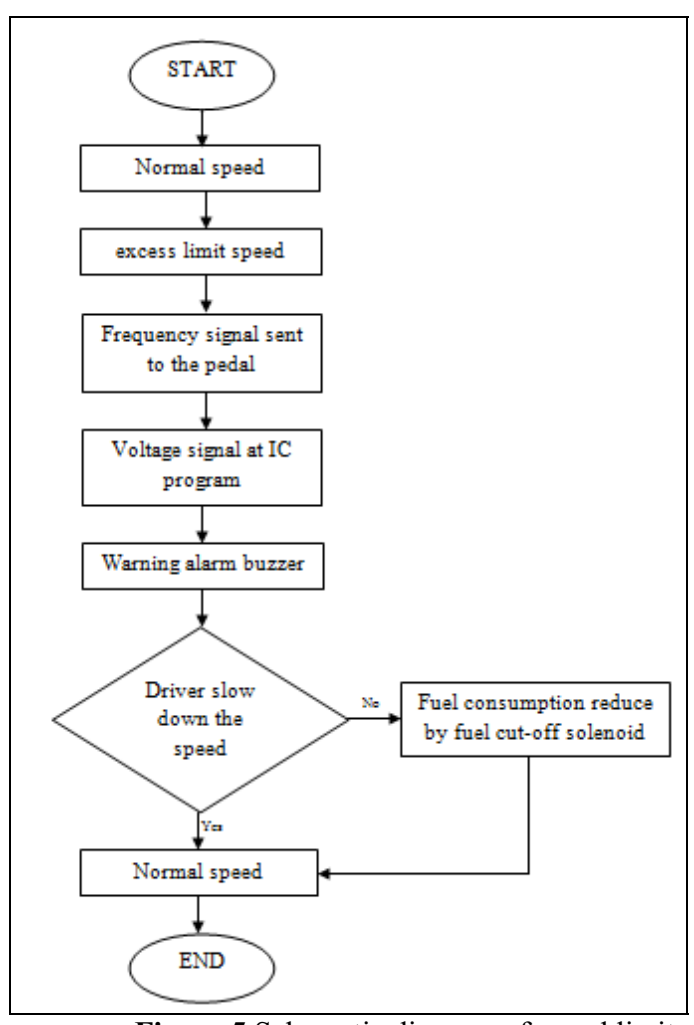

Figure 5 Schematic diagram of speed limiter

\section{Speed Limiter Development}

\subsection{Tank truck without speed limiter}

The monitoring activity has been conducted for 1 month on selected tank truck before installed speed limiter. The data is summarized in Table 2 that the highest speed is shown by tank truck with ID B 9511 UFU for $133 \mathrm{~km} / \mathrm{h}$ and the lowest speed shown by tank truck ID B 9211 $\mathrm{SEH}$ for $122 \mathrm{~km} / \mathrm{h}$. That speed is out of the regulation which mean that the attitude of the driver is not appropriate with safety driving guideline and government regulation. It causes many things such as fatigue, stress, angry that can make unstable driving condition.

Table 2 Top speed of tank truck before installing speed limiter

\begin{tabular}{|c|c|c|c|}
\hline No. & Vehicle ID & $\begin{array}{c}\text { Type of } \\
\text { Vehicle }\end{array}$ & $\begin{array}{c}\text { Top speed } \\
(\mathrm{km} / \mathrm{h})\end{array}$ \\
\hline 1 & B 9280 UU & Truck B3 & 125 \\
\hline 2 & B 9281 UU & Truck B3 & 130 \\
\hline 3 & B 9263 UU & Truck B3 & 130 \\
\hline 4 & B 9264 UU & Truck B3 & 128 \\
\hline 5 & B 9211 SEH & Truck B3 & 122 \\
\hline 6 & B 9511 UFU & Truck B3 & 133 \\
\hline
\end{tabular}

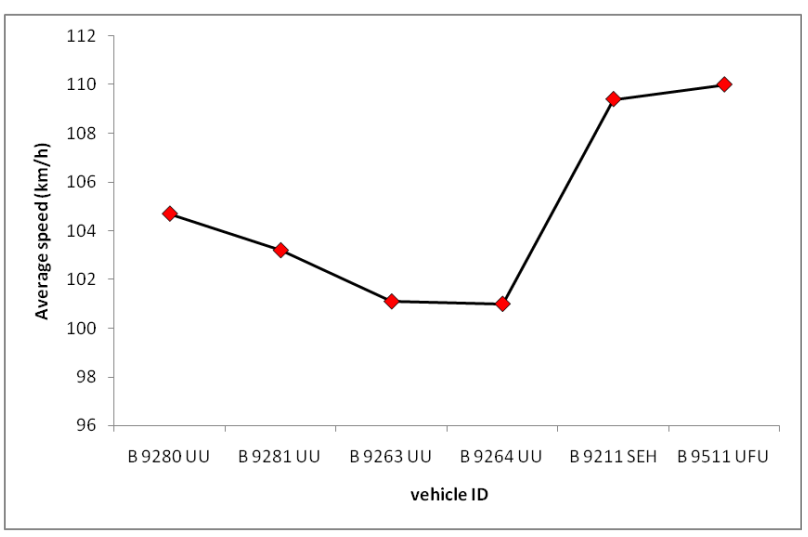

Figure 6 Average speed of tank truck before installing speed limiter

From the Figure 6 shows that the average speed of tank truck before installed by speed limiter is in above $100 \mathrm{~km} / \mathrm{h}$. Meanwhile the regulation state that the maximum speed is 70 $\mathrm{km} / \mathrm{h}$. Tank truck which commonly perform highest speed is shown by B 9511 UFU with average speed of $110 \mathrm{~km} / \mathrm{h}$ during 1 month monitoring activity and the lowest average speed performed by B $9264 \mathrm{UU}$ for $101 \mathrm{~km} / \mathrm{h}$ during 1 month. Those speed is very dangerous when performed in urban, centre of urban or residential area. It can enable for road capacity and it more possible to increase the fatalities which caused by road accident.

\subsection{Tank truck after installed by speed limiter}

Speed of tank truck monitored before installed by speed limiter has references point in speed limiter requirement. Therefore, this research investigates the influence of the speed limiter in limiting speed, improving safety riding and reducing possibility of accident. Speed limiter is installed to the tank truck, which coupled by fuel cut-off solenoid, which can automatically lock the speed in top speed regulation. The driver cannot speed up of $70 \mathrm{~km} / \mathrm{h}$ because it controlled by speed limiter. Therefore, highest speed of the tank truck is $70 \mathrm{~km} / \mathrm{h}$. It is detail listed in Table 3 and the average of speed is shown in the Figure 7.

Table 3 Top speed of the tank truck after installed by speed limiter

\begin{tabular}{|c|c|c|c|}
\hline No. & Vehicle ID & $\begin{array}{c}\text { Type of } \\
\text { Vehicle }\end{array}$ & $\begin{array}{c}\text { Top speed } \\
(\mathrm{Km} / \mathrm{h})\end{array}$ \\
\hline 1 & B 9280 UU & Truck B3 & 70 \\
\hline 2 & B 9281 UU & Truck B3 & 70 \\
\hline 3 & B 9263 UU & Truck B3 & 70 \\
\hline 4 & B 9264 UU & Truck B3 & 70 \\
\hline 5 & B 9211 SEH & Truck B3 & 70 \\
\hline 6 & B 9511 UFU & Truck B3 & 70 \\
\hline
\end{tabular}




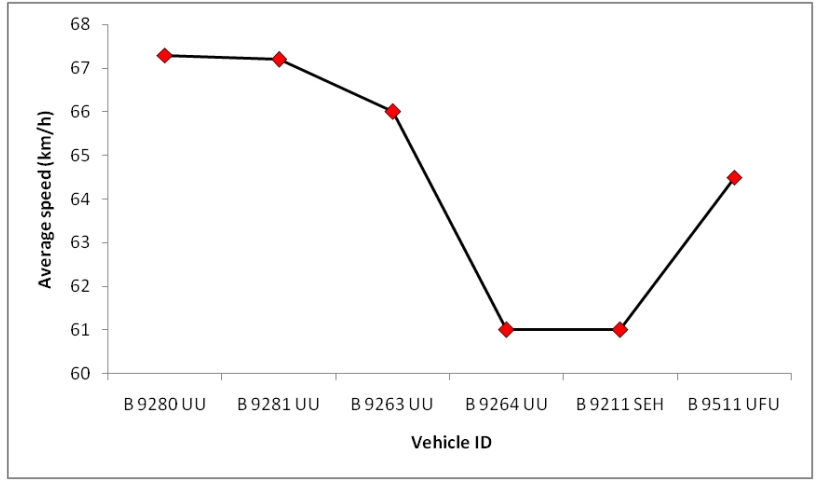

Figure 7 Average speed of tank truck after installed by speed limiter

After speed limiter is installed in selected tank truck, top speed has been locked by $70 \mathrm{~km} / \mathrm{h}$ and average speed also decreased because the driver cannot speed up. Lowest average speed is performed by B9264 UU and B $9211 \mathrm{SEH}$ for $61 \mathrm{~km} / \mathrm{h}$ and highest average speed is performed by B $9280 \mathrm{UU}$ for $67.3 \mathrm{~km} / \mathrm{h}$. Therefore, the possibility of accident can be decreased because the driver in steady or relax condition. Top speed in adjusted by government regulation that the maximum speed for tank truck is $70 \mathrm{~km} / \mathrm{h}$ in highway. Moreover, this system is purposed to the driver who able to full controlling speed of tank truck which led to safe driving could be performed by all drivers.

\subsection{The improvement and analysis after install speed limiter}

Speed limiter on the tank truck has monitored during 1 month and it can be used as references that the speed limiter is effective to control offer the speed and protect the performance of engine. Improvement is calculated from the comparison between average speeds of selected tank truck before and after installed by speed limiter shown in Figure 8. B 9263 UU shows the highest improvement for $65 \%$ and B 9211 SEH shows the lowest improvement for 56\%. This data indicated that higher $\%$ improvement will increase percentage of safe driving has been performed by tank truck driver.

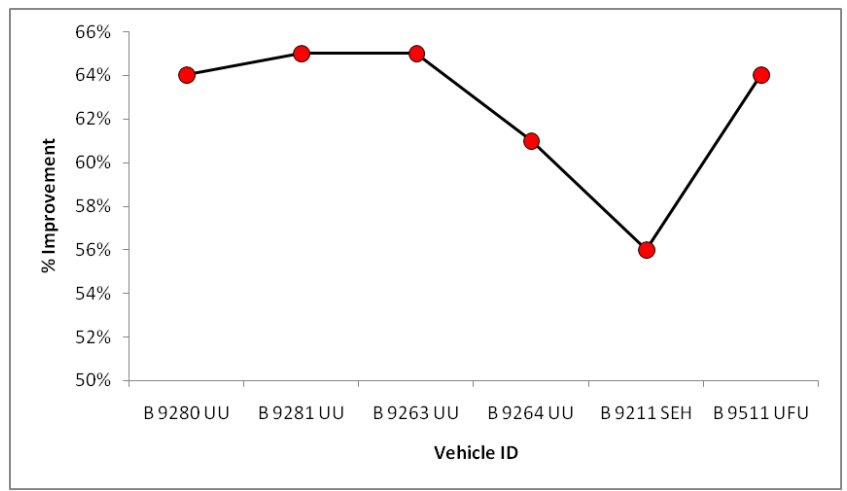

Figure 8 Percentage of improvement in speed restriction

\subsection{Report accident after installation speed limiter on the tank truck}

Table 4 shows the number of incident which recorded by july 2016. There are several decreasing incident cases observed such as in over speed and environment for 7\% and $0 \%$ as compared to last year (2015) report for $17 \%$ and $34 \%$, respectively. Significant decreament number of incident is caused by speed limiter installation on the tank truck. Decreasing incident due to speed of the tank truck is limited by fuel cut off system. Therefore, the driver disable to speed up when the speed is on the top of regulation speed. When the buzzer is on indirectly influence to the concentration and alarm when the driver sleepy. Moreover, this product is very potential to applied in the tank truck in other country and it believed able to decrease the number of tank truck incident.

Table 4 Percentage of tank truck incident for July 2016 [7]

\begin{tabular}{|c|c|c|}
\hline Incident Classification & Percentage & No. of cases \\
\hline Over speed & 7 & 3 \\
\hline Fatigue & 85 & 39 \\
\hline Premature & 9 & 4 \\
\hline Environment report & 0 & 0 \\
\hline Total cases & 100 & 46 \\
\hline
\end{tabular}

\section{Conclusion}

The effectiveness of the speed limiter in reducing the speed and control the driver is shown by speed decrement after speed limiter installed to tank truck. It performed by fuel cut-off solenoide which installed to the speed limiter system. Highest speed before installed speed limiter is $133 \mathrm{~km} / \mathrm{h}$ and after installed by speed limiter, to speed is locked at $70 \mathrm{~km} / \mathrm{h}$. It has adapted by government regulation regarding to the transportation law. From the data, it can be concluded that the speed limiter is very suitable to install in the tank truck to improve safe driving, protect the engine performance, and reduce an accident.

\section{Acknowledgement}

The authors would like to thank the Mercubuana University through the conference fees support and thanks to Pertamina Persero and Universiti Tun Hussein Onn Malaysia (UTHM).

\section{References}

1. Rencana Umum Nasional Keselamatan (RUNK), Republic of Indonesia. Technical report 2011-2022 (2010)

2. T. Tjahjono. The effect of traffic and road condition to the fatality rates on rural road in eastern Indonesia. Journal of The Eastern Asia Society for Transportation Studies, 8 (2010).

3. B.S. Dhillon. Safety and Human Error In Engineering System, (2013).

4. Regulation Ministry of Environment (KLH) No. 
74, (1999).

5. Constitution Number 22. Clause 203 Republic of Indonesia, (2009).

6. Regulation Manistry of transportation, Republic of Indonesia. PP No. 111, Procedures for determining vehicle speed limit, (2015).

7. PT. Pertamina Persero. Policy is expressed in an internal memo No. 154, (2013)

8. PT. Pertamina Persero Indonesia, Plumpang Site Report incident, (2016). 